\title{
Economic Stability and Growth: The Case of Turkey
}

\author{
Aylin İdikut Özpençe ${ }^{1, *}$ \\ ${ }^{1}$ Department of Public Finance, Pamukkale University, Denizli, 20070, Turkey \\ *Correspondence: Department of Public Finance, Pamukkale University, Denizli, 20070, \\ Turkey. E-mail: aidikut@pau.edu.tr
}

Received: October 23, 2017 Accepted: November 14, 2017 Published: November 28, 2017

doi: 10.5296/rae.v9i3.12041ＵRL: https://doi.org/10.5296/rae.v9i3.12041

\begin{abstract}
As the theory of economy began to mature, unemployment and economic growth became one of the fundamental macroeconomic indicators. Price stability, full employment and economic growth constitute the basic conditions of economic stability. If, in an economy inflation and unemployment rates reach to high levels and economic growth rates reach to low levels, economic instability will arise. In order to overcome these problems, a series of models are developed and they have taken their place in the history of economic thought. While existence of an inverse relationship was accepted between inflation and unemployment, in the 1970s and especially as the Petroleum Crisis was lived through, the concept of "stagflation" emerged. Therefore, the opinion that the thought to make a choice between inflation and unemployment should be abandoned has become widely accepted.

The aim of this study is to investigate how inflation and unemployment affects economic growth in Turkey between for the period of 2008:1 and 2017:3. In this context secondary data has been taken from Turkish Statistical Institute (TurkStat). The study differs from the previous ones because it provides research related to issues that were not investigated in previous studies related to Turkey with regards to the Industrial Production Index (IPI), Product Price Index (PPI) and the relationship of unemployment data for the long term and being related with reasoning. According to the Johansen cointegration test, there is a long term relationship between series. An increase of 1 percent in UNMP reduces IPI by 1.7 percent. Consequently, the paper recommended that in order to ensure economic growth in Turkey, especially policies that would reduce unemployment should be preferred.
\end{abstract}

Keywords: Inflation, Unemployment, Economic Growth, Johansen Co-integration

JEL Classification: E31, E24, F43, C22 


\section{Introduction}

At the point of practicing public activities, government undertakes three fundamental functions such as allocation, income distribution and economic stability (Musgrave and Musgrave, 1989: 6). The first one is the allocation function of budgeting policy and it comprises of tasks to be undertaken by the government as regards to the economy with a micro viewpoint within the frame of public economy. Tasks to be undertaken by the government in the allocation of pure public goods, quasi-public goods, merit goods, club goods etc. are handled within the framework of market failure and they are undertaken by the government. The second one is among the tasks assigned to the government for the resolution of inequalities especially originating from the structural problems of developing countries. Here topics such as efficiency, equity, and optimal taxation-consumption etc. are handled. In achieving an income distribution that is desirable or acceptable by the community, impact areas of government are accepted as a scale. Finally, economic stability is comprised of a macro viewpoint and it denotes the tools in the hands of government and the objectives required to be realized. The purpose of achieving economic stability with the tools of public and monetary policy is very important with respect to demonstration of economic performance. This situation which we can also name as macroeconomic performance forms the visible face of the country meaning its profile.

The concept of economic stability is uncertain due to its nature and it is subject to different interpretations. Therefore, variability of policies having impact on economic stability can be interpreted differently. Different policies being implemented within the body of economic stability are interrelated and they influence each other (Pasini, 2013: 235, Haberler, 1967). It is not easy to explain the concept of economic stability. In its broadest definition, economic stability is the situation where there are no extreme fluctuations or volatility in macroeconomic variables. With the indicators being chosen here, it seems possible to reach definition in the narrowest sense. However, regarding this subject no consensus has been reached in the literature as well. While economy grows, having a small ratio of inflation is deemed as being stable with respect to the economic aspects. Besides, achieving full employment makes contribution to the stable condition of economy in the narrow sense.

Within this frame, the definition being given by Stein is important as it guides us. When the definition of Stein is considered, economic stability is the situation where unemployment is low, prices are at their general levels or where there are no cumulative or sharp movements. Economic growth is related with the increase in the level of outputs, production capacity, resources, and consumption level, meaning that it is composed cumulative of these values per person, per input or per working hour. In this definition, all aspects of economic growth have been considered. And it is not required to make differentiation among them for certain purposes. However it is required to make differentiation for certain political purposes that need to be implemented (Stein, 1956: 1159-1160). The most popular among the indicators used is the Gross Domestic Product (GDP).

GDP is the total value of goods and services produced within a country at in a given period of time. In the study Industrial Production Index (IPI) is used instead of GDP. IPI is an indicator 
of the change in the production of firms in the industrial sector. Inflation is defined as a constant increase in the general level of prices for goods and services. In the study PPI is used. PPI shows to changes in the index which made from goods and services produced domestically. According to International Labor Organization (ILO), the definition of unemployment is people who are searching work for the last four weeks but cannot find work. There are four types of unemployment in an economy. The first of these is frictional unemployment namely temporary unemployment. The second is the structural unemployment which comes from the incompatibility between existing labor force demand in the market and the skills of existing workers in the market. The third is cyclical unemployment which results from conjuncture or business cycle fluctuations. Finally, natural unemployment is the sum of structural unemployment and frictional unemployment.

Economic stability is divided into internal stability and external stability. Internal stability provides to price stability, full employment and economic growth. The deterioration of internal stability is manifested in the form of inflation and unemployment. The other aspect of economic stability namely external stability is ensured the balance of payments. Internal stability is taken into account in this paper.

Basic targets of this study are;

i. As being different from the studies done relating to how inflation and unemployment influences economic growth, to look at the production aspect of economy and to make contribution for the literature,

ii. To investigate the impact of inflation (PPI) and unemployment on industrial production for the period between 2008:1 and 2017:3 for Turkey,

iii. To research the short term and long term relationship among dependent variables (IPI) and independent variables (PPI and unemployment),

iv. To investigate the causality relationship between dependent variable (IPI) and independent variables (PPI and unemployment),

v. To make evaluations and inform the policy makers.

Within this context, the policies that were implemented in Turkish economy from the time of establishment of republic in 1923 till today are given in Table 1 as a summary. In Table 1 the periods and determining factors are classified and inflation, unemployment, and economic growth figures have been exemplified. 
Table 1. Key Determinants of the Turkish Economy

\begin{tabular}{|c|c|c|}
\hline Periods & Determining Factors & Economic Stability and Growth \\
\hline $\begin{array}{l}\text { 1923-1929 } \\
\text { Liberal Policies }\end{array}$ & $\begin{array}{l}\text { The Turkish War of Independence } \\
\text { Effect of First World War } \\
\text { İzmir Economic Congress } \\
\text { Law for the Encouragement of Industry } \\
1929 \text { World Economic Crisis }\end{array}$ & $\begin{array}{l}\text { Economic growth rate of Turkey was } 21,5 \\
\text { percent in } 1929 . \\
\text { Inflation rate was on average } 80 \text { percent in } 1929 . \\
\text { Unemployment rate was } 9.1 \text { percent in } 1923 \text { and } \\
3.14 \text { percent in } 1929 \text {. }\end{array}$ \\
\hline $\begin{array}{l}\text { 1930-1939 } \\
\text { Etatism Policies }\end{array}$ & $\begin{array}{l}\text { Planned Economic Development } \\
\text { Strategy } \\
\text { The government took an active role in } \\
\text { economic activities } \\
\text { First Five Year Industry Plan was } \\
\text { implemented from } 1934 \text { to } 1938 \text {. } \\
\text { The Second Five Year Industry Plan } \\
\text { couldn't be completely implemented } \\
\text { because of World War II. Instead } \\
\text { Economic Defense Plan went into } \\
\text { effect in 1939. }\end{array}$ & $\begin{array}{l}\text { Economic growth rate } 2.2 \text { percent in } 1930 \text { and } \\
23.1 \text { percent in } 1936 \text {. } \\
\text { Inflation rate was }-7.8 \text { percent in } 1930 \text { and } 2.2 \\
\text { percent in } 1939 \text {. } \\
\text { Unemployment rate was } 3.2 \text { percent in } 1930 \text {. }\end{array}$ \\
\hline $\begin{array}{l}\text { 1940-1950 } \\
\text { Transition } \\
\text { Process to } \\
\text { Liberalization }\end{array}$ & $\begin{array}{l}\text { World War II } \\
\text { Outward open growth policy after } \\
1947 . \\
\text { Marshall Plan } \\
\text { First multi-party elections were held in } \\
1946 . \\
\text { Turkey became a member of the IMF } \\
\text { and World Bank in } 1947 \text {. }\end{array}$ & $\begin{array}{l}\text { Economic growth rate was }-15.3 \text { percent in } \\
1945 \text {. } \\
\text { Inflation rate was } 8.5 \text { percent in } 1940 \text { and }-4.3 \\
\text { percent in } 1950 \text {. } \\
\text { Unemployment rate was } 2.4 \text { percent in } 1940 \text {. }\end{array}$ \\
\hline $\begin{array}{l}\text { 1950-1960 } \\
\text { Liberalism } \\
\text { Process }\end{array}$ & $\begin{array}{l}\text { Period of decline of Etatism } \\
\text { Turkey became a member of the NATO } \\
\text { in } 1952 \text {. } \\
1958 \text { moratorium } \\
\text { Military intervention in } 1960\end{array}$ & $\begin{array}{l}\text { Economic growth rate was } 9.4 \text { percent in } 1950 \text {. } \\
\text { Inflation rate was } 22.6 \text { percent in } 1959 . \\
\text { Unemployment rate was } 3.2 \text { percent in } 1956 \text {. }\end{array}$ \\
\hline $\begin{array}{l}\text { 1960-1970 Mixed } \\
\text { Economic Policy }\end{array}$ & $\begin{array}{l}\text { Transition to planned development } \\
\text { economy } \\
\text { Import Substitute Industrialization } \\
\text { Strategy } \\
\text { The First and The Second Five Year } \\
\text { Development Plan }\end{array}$ & $\begin{array}{l}\text { Economic growth rate was } 2.9 \text { percent in } 1960 \text {. } \\
\text { Inflation rate was } 7.4 \text { percent in } 1960 \text { and } 1.3 \\
\text { percent in } 1961 \text {. } \\
\text { Unemployment rate was } 3.1 \text { percent in } 1960 \text {. }\end{array}$ \\
\hline $\begin{array}{l}\text { 1970-1980 } \\
\text { Introduction to }\end{array}$ & $\begin{array}{l}\text { The Third Five Year Development Plan } \\
1973 \text { First Oil Crisis }\end{array}$ & $\begin{array}{l}\text { Economic growth rate was } 2.9 \text { percent in } 1978 \\
\text { and }-0.3 \text { percent } 1979 .\end{array}$ \\
\hline $\begin{array}{l}\text { Free Capital } \\
\text { Flows Process }\end{array}$ & $\begin{array}{l}1974 \text { Cyprus Peace Operation } \\
\text { 1979-80 Second Oil Crisis }\end{array}$ & $\begin{array}{l}\text { Inflation rate was } 52.6 \text { percent in } 1978 \text { and } 63.9 \\
\text { percent in } 1979 \text {. } \\
\text { Unemployment rate was } 10.1 \text { percent in } 1978 \\
\text { and } 8.9 \text { percent in } 1979 .\end{array}$ \\
\hline
\end{tabular}


1980-1990

Liberalization of

Goods

Movements

1990-2000 Full

Liberalization in

Goods and

Capital

Movements

Process

2000-2010 Crises

and Structural

Reforms Process
The Fourth and The Fifth Five Year

Development Plan

24 January 1980 Economic Stability

Program

Military intervention in 1980

Liberalization of Short-Term Capital

Movements

Export-Based Growth Model

The Sixth and The Seventh Five Year

Development Plan

Fiscal Liberalization

Gulf, Asian and Russian Crises

5 April 1994 Decisions

November 2000 and February 2001

crises

Transition to Floating Exchange Rate

Regime

Inflation Targeting (Nominal Anchor)

Transition to the Strong Economy

Program

The Eight and The Ninth Five Year

Development Plan

2002 Emergency Action Plan

Public Finance Management and

Control Law 5018

2008 Global Financial Crisis

2010-beyond

Global

Contraction and

Terrorism
European Debt Crisis

The Tenth Five Year Development Plan

Economic growth rate was -6.1 percent in 1994 and 6.3 percent in 2000 .

Inflation rate was 104.4 percent in 1994 and 56.3 percent in 2000 .

Unemployment rate was 9.1 percent in 1994 and 6.5 percent in 2000 .

Economic growth rate was -5.7 percent in 2001 and 9.4 percent 2004 .

Inflation rate was 54.3 percent in 2001 and 8.8 percent in 2004.

Unemployment rate was 8.4 percent in 2001 and 10.3 percent in 2004 .

and 9.4 percent 1990 .

Inflation rate was 70.5 percent in 1988 and 52.3 percent in 1990.

Unemployment rate was 8.4 percent in 1988 and 7.4 percent in 1990 . 
in import has begun in 1984-1989. Free movement of capital caused hot money flow after 1988 and this situation increased imports and consumption.

Transition to the Strong Economy Program implemented after the crises of November 2000 and February 2001 includes a series of measures such as structural innovations, banking system reforms, inflation targeting, floating exchange rate regime and narrowing of public expenditures. 2002 Emergency Action Plan relied mainly on privatization, tax-expenditure reforms and restructuring of reel sector. Strict monetary and fiscal policies provided an environment of economic stability. However this situation sustained until the 2008 global financial crisis. The crisis affected all sectors especially real sector.

In this context the government took a series of measures which ones employment and tax support. These measures are still being implemented today. The development of vocational training activities, the provision of entrepreneurship and educational counseling services and the provision of premium support for additional employment above the current employment has been fulfilled by Turkish Labor Agency. Within scope of Employment Mobilization; workers' net minimum wage and work accidents occupational diseases and general health insurance premiums has paid by the Unemployment Insurance Fund. For the purpose of domestic and foreign assets to gain of national economy a law called "Asset Amnesty-Capital Repatriation" has been enacted. Turkey is one of the economies still living in high inflation and unemployment compared to global economy.

The following sections of the study are specified such that in the second section it is mentioned about inflation, unemployment, and theoretic and empirical explanations in the area of economic growth. In the third section, information is given about the empirical model that is implemented and the relevant methodology. Besides this, the empirical findings are also stated. The study is finalized with the conclusion section.

\section{Theoretical Framework}

\subsection{Unemployment and Inflation}

There are two main factors for the public policy to provide economic stability. While the first one of these is to ensure price stability, the other one is to achieve full employment. This situation which we define as struggling with inflation and unemployment causes for different interpretations to be made with regards to economic thoughts. Such that many theories ranging from the definition of inflation and unemployment to the relevant reasons and to economic impacts and solution ways have been revealed. According to classical economic thought unemployment and inflation arises in the short run. In the long run unemployment and inflation will balance automatically because of the flexible of prices and wage.

The exchange, meaning the negative relationship between money wage and unemployment is handled in a study that is carried out by Phillips (1958) in England between the dates of 1861-1957. He argued that changes in the demand for labor lead to changes in the money wage rate. Contribution of Phillips was that he enabled for the relation between monetary 
wages and unemployment to be stable. When frictional unemployment rate is 5.5 percent, monetary wages are stable. The inverse relationship between money wage and unemployment in short term is usually explained using the Phillips curve. Keynesians have asserted that inflation arose as total demand exceeded total supply and that policies aiming for demand had to be implemented. Besides, there is trade-off between inflation and unemployment. In the other words the inverse relationship put forward by Phillips (1958) is meaningful. Because there is wage rigidity.

According to neoclassicals there is a trade-off relation between inflation and unemployment. For policy makers, this is a choice alternative. It is important to understand that in terms of neoclassical point of view even if there is unemployment in the economy, labor supply must be higher than labor demand, and the real wage must be above the equilibrium level (Forstater, 2002).

Samuelson and Solow have investigated the relationship established by Phillips, within the scope of inflation and unemployment rate. He has asserted that trade-off between inflation and unemployment was valid for short term and that there was no such relationship in the long term. Samuelson and Solow who explained cost push against demand pull and seller inflation against wage push and the inflation with demand changes, as being established to explain the reasons of price fluctuations and varieties of inflation, have asserted that these concepts were intertwined (Samuelson and Solow 1960). In 1962 it was asserted by Okun that there was a negative relationship such that economic growth reduced unemployment and this assertion is accepted in the literature of economics as the Law of Okun. Any extra percent increase above four percent unemployment rate will reduce real GNP by about three percent (Okun, 1962). As a result of stagflation that came out at the end of 1960s and at the beginning of 1970s, original Phillips curve began to be questioned.

According to monetarists, inflation is a monetary phenomenon. For this reason, monetary authority will struggle with inflation by means of monetary policy. Friedman has reviewed the relation between inflation and unemployment under two headings such as short term and long term and he asserted that there won't be any trade-off in the long term. Because in the long term, both with respect to capital and labor force, there is the influence of unexpected changes in nominal demand in the markets (Friedman, 1968, 1976). In the long term, unemployment rate occurs at natural rate of unemployment and the inflation rate is realized as per the expected inflation rate.

The natural rate of unemployment that is asserted by Friedman (1968) and Phelps (1968) is that in the long term unemployment would reach its natural rate and that there wouldn't be any trade-off with the inflation. Meaning that long term Phillips curve is vertical on the natural rate. However in the short term there is a trade-off relation between unemployment and inflation. The adaptive expectations argument of Friedman is based on the assumption that economic units shape their expectations as per the past events. The criticisms of adaptive expectations were developed through Rational Expectations thesis by Muth (1961). Rational Expectations thesis that is evaluated within the frame of opinion that dynamic economic models cannot be assumed to be sufficiently rational and that the individuals are rational was 
developed by Lucas (1972) and it has significantly contributed for the establishment of New Classical models.

New classical models bear the assumption that prices are continuously adjusted to balance the demand and supply. By emphasizing on the flexibility of wages and prices, they have stated that economic units would not be mistaken regarding their short term and long term expectations. Thus, an analysis at micro economic basis has been conducted (Mankiw, 1990). Lucas (1972), has stated that economic units took decisions by evaluating past and current information. Individuals act rationally but since they have missing information, they cannot take correct decisions (Lucas, 1972: 103-104). When economic units establish their expectations in a rational way, the policies being implemented won't contribute for increasing production or reducing unemployment. If a policy is being predicted, prices and wages will be adjusted as per the situation (Eker, Altay and Sakal, 1997). In other words, policies causing people to have rational expectations to make wrong predictions and to manipulate the economy, would cause more disruption in the economy (Ulusoy, 2016). Thus, according to New Classics, there is no trade-off relation between inflation and unemployment both in the short term and in the long term. Phillips curve is vertical for both periods.

Academic discussions on inflation and unemployment trade-off include whether of wages and prices are nominal or real. New Keynesian theory is based nominal wages and prices rigidities. In order to avoid demand shocks, government can intervene with the economy. However, this intervention can create real influences in cases of menu costs, implicit contracts and efficiency wages. New Keynesians, who evaluated inflation expectations for the future, have asserted the concept of non-accelerating inflation rate of unemployment (NAIRU). NAIRU is nearly a synonym for the natural rate of unemployment. NAIRU concept which entered macroeconomics in 1970s has decreased in ratio as productivity and competitiveness increased in 1990s (Ball and Mankiw, 2002: 115).

\subsection{Economic Growth}

In classical growth models, economic growth is accepted as being equivalent to capital accumulation. Making savings is a virtue. Savings have a major role in capital accumulation. Each saving that is converted to investment will contribute for economic growth. Growth can be achieved in the short term. In the long term as prices and wages are flexible and there is the assumption of full employment, economic growth has remained behind the curtain. With the theories of Adam Smith such as division of labor, specialization, the theory of absolute advantages, labor productivity, population increase, free trade, invisible hand, and free competition, country economies will be able to achieve economic growth. Thomas R. Malthus has asserted that population increased geometrically and that food products increased arithmetically and he stated that in agriculture, law of diminishing returns was valid. According to David Ricardo, determinants of economic growth are physical capital stock and labor force.

Classic growth models are based on the assumptions that there is full employment and full competition in the economy. According to Keynesians, economy can be in a market with deficient employment and deficient competition. Within this framework, according to Kaldor, 
the purpose of economic growth is to reveal the nature of variables that are not economical and which determine the level of general production in the economy. In this way, it is possible to answer to the question about why some communities grow faster than others. There is a general consensus about the critical factors that determine economic growth trends. These factors are the tendency of community to make savings, innovation that determines the increase rate in efficiency, and the increase in population (Kaldor, 1957).

Harrod-Domar have stated that in the long term, economic systems would cause economic growth to be balanced on a knife edge. If the parameters of saving ratio, capital accumulation ratio, and rate of increase in labor force deviate from the stable state of equilibrium, either unemployment or inflation would occur. According to Harrod if there are no technological changes, the natural economic growth rate is dependent on the increase ratio of labor force and the required growth rate is dependent on saving habits of companies and individuals. Besides, with the instruments to be implemented in short term, it will be worked to find solutions for problems in the long term (Solow, 1956). The Harrod-Domar economic growth model is a long term equilibrium theory that evaluates economies with full employment as being dependent on external variables such as economic growth, population increase, and technical advancement (Alkin, 1969).

According to Domar (1946), the standard Keynesian system does not provide us tools regarding equilibrium growth rate. Under the assumption that full employment is a function of national income, there is no economic growth problem. Domar, who stated that this assumption could only be valid for the short term, revealed that different labor employments are shown in the same ratio of insufficient capacity, idle machinery and efforts. Because according to Keynesian system, investment is only an instrument used in generating income. However, the system has disregarded that investment also increases efficiency capacity (Domar, 1946). Harrod has accepted the underemployment equilibrium and Domar has accepted full employment equilibrium on a theoretical basis and they have calculated balanced growth rate at full employment equilibrium point by using the accelerator and multiplier coefficients (Harrod, 1939: 16; Domar, 1946: 138).

The importance attached to the employment equilibrium by Harrod-Domar growth models is also revealed in neoclassical growth models. In the economic growth phase, the importance of physical capital and the labor force is emphasized once again. The neoclassical growth model which evaluates economic growth with a short term viewpoint, assumes that target growth will be achieved with the increases in capital stock as per the production function based on decreasing efficiencies according to the scale. In the long term countries will converge. According to the idea that is accepted as Solow-Swan growth model, labor force, capital and technology are basic determinants on economic growth.

In the neoclassical growth model according to Solow, economy policies may not change the rate of economic growth in steady state of equilibrium. For this reason government has a smaller share in the economy (Solow, 1956). Meaning that in economy even if capital stock will be reduced, as the savings will remain fixed, even in steady state of equilibrium, economic growth will increase. Critics of the neoclassical growth model which considers 
technology, research-development and human capital as exogenous factors, was made with the endogenous growth models. In endogenous growth models, public sector intervenes with the economy with reasonable ratios. This is achieved this by means of externalities such as values of human capital, technology, innovation and information (Lucas, 1988, Romer, 1986, Barro, 1990). In the endogenous growth theories, emphasize is given on how technology can be developed. Technology is not exogenous but endogenous and there is no question of diminishing return.

\section{Literature Review}

In the literature, there are various studies investigating the relation between inflation and growth, unemployment and growth or inflation and unemployment. However, the number of studies investigating the relation of inflation, unemployment and growth simultaneously is very few. From this aspect, it is thought that the study will contribute to the literature.

Thayaparan (2014), has tested the impact of inflation and economic growth on unemployment by using a Granger causality analysis with the data covering the periods between years of 1990-2012 for the Sri Lankan economy. While there is a one directional causality between inflation and unemployment, there is a multi-dimensional relation between unemployment and economic growth. While the inflation coefficient is negative and its impact on unemployment is significant, coefficient of economic growth is positive and it does not have a significant impact on unemployment.

In their study where they investigated the relation between inflation, unemployment and economic growth in Nigerian economy for the period between years of 1987-2012 as per Ordinary Least Square (OLS) method, Yelwa et al (2015) determined that inflation and unemployment had reverse impact on economic growth. In a different study Sa'idu and Muhammad (2015) revealed a one-way causation flowing from inflation to GDP and that unemployment does not causes economic growth and inflation.

In his study in which he investigated the Jordan economy, Jaradat (2013) analyzed the impact of inflation and unemployment on economic growth by using the data for the period between 2000 and 2010 by implementing Granger causality analysis. While there is a negative relation unemployment and economic growth, there is a positive relation between inflation and economic growth.

In their study on the Pakistani economy for the years between 1973 and 2010, Wajid ve Kalim (2013) have evaluated the short term and long term impact of inflation, trade openness, economic growth and urban population on unemployment, by using the Granger causality analysis. While inflation is influential on unemployment in the long term, there is no such relationship in the short term. Besides, while economic growth reduces unemployment significantly in the long term, the influence of economic growth on unemployment is in a negative direction. But unemployment has insignificant impact on changes in economic growth in the short term. In his study on the Pakistani economy for the period of 1980-2010 where he investigated the impact of inflation and unemployment on economic growth, Shadid 
(2014) used the Auto-regressive Distributed Lag (ARDL) method. According to ARDL results, it can be seen that the influence of inflation and unemployment on economic growth was insignificantly negative and significantly negative respectively. Also according to the ARDL model result there is a long run relationship between inflation, unemployment and economic growth. In another study conducted by Umair and Ullah (2013), for the period of 2000-2010 while inflation had an important role, GDP and unemployment had insignificance levels in macro-economic factors of Pakistan.

Vermeulen (2015) tested the relationship of inflation, economic growth and employment for South Africa for the period between 1961 and 2011 by using Engle-Granger ECM. According to test results, there is a co-integrating long-run relationship between employment and economic growth. In the short term, the influence of inflation on employment is not positive.

Jelilov et al (2016) have evaluated the data for the period between years of 2001-2014 to investigate the relation between economic growth, inflation and unemployment for economies in Economic Community of West African States (ECOWAS) such as Nigeria, Benin, Cape Verde Islands, Ivory Coast, Gambia, Ghana, Guinea Bissau, Mali, Nigeria and Senegal (10 countries). As per the outcome of regression analysis for 10 countries obtained by using OLS and by referring to the equation of Law of Okun, it is revealed that unemployment influences economic growth. Inflation is especially influential in increasing income per person.

Asari et al (2011) have evaluated the relation between inflation, employment and gross national product for years $1982-2006$ by using Granger causality test. Accordingly inflation and employment influences gross national product in the short term. In the long term, there is no relation between inflation and gross national product. However, there is a negative relation between employment and gross national product.

Mohseni and Jouzaryan (2016), have tested the relation between inflation, employment and economic growth for Iran economy between the years of 1996-2012 by using ARDL model. ARDL tests the existence of short term and long term relation between the variables. Accordingly, when test results are reviewed it is seen that in the long term, inflation and unemployment has a negative and meaningful impact on economic growth.

Yüksel (2016), who investigated the causality relation between economic growth, unemployment and inflation in Russia, determined that there is a causality relation from unemployment towards economic growth and from inflation to unemployment for the period between 1992 2014. As a political target he proposed that policies aiming to reduce inflation should be avoided and that it should be struggled directly with unemployment.

Resurreccion (2014), has investigated the relation between inflation, unemployment and growth for the economy of Philippines between the years of 1980-2009. In his study to which he has added the age dependency ratio, while unemployment is negatively related with inflation and economic growth, the age dependency ratio has a positive but meaningless relation to unemployment.

In his study in which he investigated the relation between economic growth, unemployment 
and inflation in Turkey, Köse (2016), has determined a negative relation between inflation and unemployment for the period between 2003:03 and 2014:04. In another study Şentürk and Akbaş (2014), determined a double directional causality relation between industrial production index, inflation and unemployment for the period from 2005:01-2012:07. Şahbudak and Şahin (2016), who investigated the relation between GDP, inflation and population growth rate by using the ARDL method, he has found a negative and significant relation between variables and he has observed a negative and insignificant relation between GDP and unemployment in the short term. While there is a negative and significant relation between inflation rate and unemployment rate, there is a positive and significant relation between population growth rate and unemployment rate.

\section{Findings}

\subsection{Data and Methodology}

The data used in this study is time series data for the time period of 2008:1 and 2017:3. The data is collected from TurkStat. In the study, relation between IPI, PPI and unemployment in Turkey is investigated. The seasonal and calendar effect is adjusted for the data.

As it takes time to gather economic growth data, it takes a long time to publish quarterly data. For this reason, the capability to make predictions for the future is reduced for the decision makers. In order to cover for this deficit, IPI is being published on a monthly basis, its relation with economic growth being supported with theoretical and empirical studies (Kaldor, 1957; Fulop and Gyomai, 2012). In the study to be able to make analysis with monthly data, the IPI has been chosen as a good proxy for GDP. Because industrial production is seen as the locomotive of economic growth. It responds more quickly to demand and supply shocks.

The PPI and Consumer Price Index (CPI) causality relationship is different from according to supply side approach and demand side approach. With respect to supply side approach, changes in PPI lead or cause CPI while demand side approach CPI leads PPI (Akçay, 2011; Arby and Ghauri, 2016; Clark, 1995). In the study it is decided to use PPI data as representing inflation. Because as IPI represents production side of economy, by using PPI as a complementary data, a complete perspective from production aspect is demonstrated. Due to the changes done in calculating the unemployment data in Turkey, these data are only meaningful after 2005 with respect to empirical studies. In the study, to investigate the probable impact of the global financial crisis of 2008 on Turkey, the starting time for the data is taken as year 2008. In order to determine whether there is a cointegration relation between time series in econometric models first of all the series should not be in the unit root.

In order to determine whether there is a cointegration relation between time series in econometric models or not, first of all it is required for series not to contain unit roots. Determining that data are stationary enables for statistically correct results to be obtained. If time series are stationary, it means that relation between time and variables is independent (Gujarati, 2004: 817-818). 
In the study stability of series is investigated with an Augmented Dickey Fuller (ADF) and a Phillips-Perron (PP) Unit Root Test. It is assumed that the Dickey-Fuller Unit Root Test (DF) error term average is zero and that it has a normal distribution, a constant variance (namely no heteroscedasticity), and a stochastic structure that does not contain autocorrelation, meaning that error term is white noise (Dickey and Fuller, 1979: 427). If there is no White Noise but autocorrelation, by including lag values for dependent variables, in order for OLS predictions to be made much healthier by developing DF test, ADF test has come out. In ADF unit root test, equality (1) is predicted and it is tested whether $(\alpha, \rho)=(0,1)$ parameter is such that $\alpha \neq 0$ and $\rho=1$ or not as statistically. Accepting that $\alpha$ parameter is different from zero, shows that series is stationary at level (Dickey and Fuller, 1981: 1069-1070).

$$
\Delta Y_{t}=\beta_{1}+\beta_{2} t+\delta Y_{t-1}+\sum_{i=1}^{m} \propto_{i} \Delta Y_{t-i}+\varepsilon_{t}
$$

In the equation with number (1), the situation where both the constant and trend impact are observed is shown. $\Delta$ defines first difference processor, $\mathrm{t}$ defines time trend, $\varepsilon_{\mathrm{t}}$ defines error term, $Y_{t}$ defines the series being used. In the equation with number (1), it is tested whether $\Delta$ coefficient is statistically equal to zero or not.

PP use non-parametric statistical methods observe the serial correlation in the error terms without adding lagged difference terms. The PP test is the same as the ADF test statistic (Gujarati, 2004: 817-818). PP test which allows for error term to be distributed as weakly dependent and heterogeneously, eliminates the problem of PP test autocorrelation and equality is being predicted (2.1, 2.2 ve 2.3) (Phillips and Perron, 1988: 337-338).

$$
\begin{array}{cc}
\mathrm{yt}=\alpha \mathrm{yt}-1+\mathrm{ut} \quad(\mathrm{t}=1,2, \ldots) & \alpha=1 \\
\mathrm{yt}=\mu^{*}+\alpha^{*} \mathrm{yt}-1+\mathrm{ut} * & \\
\mathrm{yt}=\mu^{*}+\beta^{*}(\mathrm{t}-1 / 2 \mathrm{~T})+\alpha^{*} \mathrm{yt}-1+\mathrm{ut} * & \mu=\beta=0
\end{array}
$$

Johansen's cointegration test takes its starting point in the vector autoregression (VAR) of order k given by (Johansen, 1988: 232)

$$
\mathrm{Xt}=\Pi_{1} \mathrm{X}_{\mathrm{t}-1}+\Pi_{2} \mathrm{X}_{\mathrm{t}-2}+\ldots \ldots \ldots \ldots \ldots+\Pi_{\mathrm{k}} \mathrm{X}_{\mathrm{t}-\mathrm{k}}+\mathrm{u}_{\mathrm{t}} \quad \mathrm{t}=1,2, \ldots,
$$

for given values of $X_{-k+1}, \ldots, X_{0}$. Here $X_{t}$ is an $n \times 1$ vector of variables as being integrated of order one, where $\mathrm{I}(1), \mathrm{u}_{\mathrm{t}}$ is an $\mathrm{n} \times 1$ vector of innovations while $\Pi_{1}$ through $\Pi_{\mathrm{k}}$ are $\mathrm{m} \times \mathrm{m}$ coefficient matrices.

Here Xt defines non-stationary level variable vector and the error-correction mechanisms.

In the equation with number (3.1), it is focused on $\Pi$ matrix and its rank. Cointegration is investigated for this matrix rank. For example, if the rank of a П matrix with the size of $\mathrm{n} \times \mathrm{n}$ is 0 , all the elements of $\mathrm{Xt}$ containing $\mathrm{n}$ variable in the model, consists unit root. If the number of variables forming $\mathrm{Xt}$ vector in the rank model is equal to $\mathrm{n},(\mathrm{r}=\mathrm{n}), \mathrm{Xt}$ is a stationary system. If $\mathrm{r}<\mathrm{n}$, among the elements of $\mathrm{Xt}$, there is a cointegration relation between the elements for at most n-1 number (Demiray, 1998: 70). 


\section{Ml Macrothink}

In other words $X_{t}$ is integrated of order 1 , such that $\Delta X_{t}$ is stationary, and impact matrix (Johansen, 1988:232);

$$
\mathrm{A}(\mathrm{z}) \mid \mathrm{z}=1=\Pi=\mathrm{I}-\Pi 1-\ldots-\Pi \mathrm{k}
$$

has rank $\mathrm{r}<\mathrm{p}$. Namely,

$$
\Pi=\alpha \beta
$$

In the equation with number (3.3), cointegration hypothesis is defined as a reduced rank of $\Pi$ matrix. In Johansen cointegration method, by predicting $\Pi$ matrix from unrestricted VAR, validity of specified conditions is tested with reduced rank of $\Pi$.

The purpose of cointegration analysis is to find $\beta$ ' matrix and to separate $\mathrm{X}_{\mathrm{t}}$ into stationary and unstationary parts. For this to be achieved, first of all it is required to determine rank (r) (Demiray, 1998: 70). Johansen's method is implemented on two likelihood ratio tests; trace ( $\left.\lambda_{\text {trace }}\right)$ ve maximum eigenvalue $(\lambda \mathrm{mak})$ with which rank is determined. Maximum eigenvalue test statistic is;

$$
\mathrm{LR}(\mathrm{r} 0, \mathrm{r} 0+1)=-\mathrm{T} \ln (1-\lambda \mathrm{r} 0+1)
$$

Where $\operatorname{LR}(\mathrm{r} 0, \mathrm{r} 0+1)$ is the likelihood ratio test statistic for testing whether rank $(\Pi)=\mathrm{r} 0$ versus the alternative hypothesis that rank $(\Pi)=r_{0}+1$. If $\lambda_{1}=0$, then the rank of $\Pi$ is zero and there are no co-integrating vectors (Dwyer, 2015:5). The trace test is a test whether the rank of the matrix $\Pi$ is $\mathrm{r} 0$.

$$
L R(r, n)=-T \sum_{i=r 0+1}^{n} \ln (1-\lambda \mathrm{i})
$$

where $\operatorname{LR}(\mathrm{r} 0, \mathrm{n})$ is the likelihood ratio statistic for testing whether rank $(\Pi)=\mathrm{r}$ versus the alternative hypothesis that rank $(\Pi) \leq \mathrm{n}$ (Dwyer, 2015:6).

\subsection{Findings}

In this study it is investigated whether PPI and UNMP has an impact on IPI or not.

Table 2. Descriptive Results

\begin{tabular}{lllll}
\hline Variables & Minimum & Maximum & Mean & Std. Deviation \\
\hline IPI & -21.3 & 19.8 & 2.83 & 7.44 \\
PPI & -3.75 & 18.4 & 7.34 & 4.39 \\
UNMP & 8 & 13.9 & 10.2 & 1.41 \\
\hline
\end{tabular}

Table 2 provides descriptive information about IPI, PPI and UNMP. As it can be seen from Table 2, minimum and maximum values of IPI have changed much between January 2008 and March 2017. This change is the outcome of reduction being lived through in the world as a result of global finance crisis in 2008 . 
Table 3. Result of Unit Root Tests

\begin{tabular}{lcccc}
\hline \multicolumn{4}{c}{ Augmented Dickey-Fuller Test Results } \\
\hline Variables & \multicolumn{2}{c}{ Level } & \multicolumn{2}{c}{ First Difference } \\
\hline \multicolumn{2}{r}{ Intercept } & Trend and Intercept & Intercept & Trend and Intercept \\
\hline IPI & -2.2862 & -2.2919 & $-11.6169^{*}$ & $-11.5614^{*}$ \\
PPI & -2.9819 & -2.8771 & $-6.4790^{*}$ & $-6.4984^{*}$ \\
UNMP & -1.8855 & -1.8824 & $-3.0905^{* *}$ & $-6.5665^{*}$ \\
\hline
\end{tabular}

Phillips-Perron Test Results

\begin{tabular}{lcccc} 
& \multicolumn{2}{c}{ Level } & \multicolumn{2}{c}{ First Difference } \\
\hline & Intercept & Trend and Intercept & Intercept & Trend and Intercept \\
\hline IPI & -2.5577 & -2.5688 & $-11.5406^{*}$ & $-11.4910^{*}$ \\
PPI & -2.6176 & -2.5389 & $-6.4801^{*}$ & $-6.4735^{*}$ \\
UNMP & -1.6334 & -1.6410 & $-6.8934^{*}$ & $-6.8690^{*}$ \\
\hline
\end{tabular}

Note: Mac Kinnon*,**,*** shows the critical values of $\% 1, \% 5$ and $\% 10$ respectively.

The unit root test shows whether the variables are stationary. In order to determine whether there are long term relations between series, unit root tests are conducted. When Table 3 is investigated, as per ADF and PP test results, it is seen that all series have unit roots with a significance level of 1 percent and 5 percent. As the series are nonstationary at the level, their first differences are taken. When their first differences are taken, the series became stationary with significance level of 1 percent and 5 percent. In order for Johansen cointegration test to be applied, it is required for series to be stationary at the same level. As the series were stable in their first differences in the study, Johansen cointegration test is realized.

The most widely used statistics for determining the lag length of VAR (Vector Autoregressive Model) model are the Akaike Information Criterion-AIC, the Schwarz Information Criterion-SC and the Hannan-Quin Information Criterion-HQ. Lag length which makes these information criteria become minimum is considered to be optimal. In this study, the optimal lag length is found to be 2 according to SC and HQ and 11 as per AIC information criteria. However since model verification tests in lag length are nonstationary as per SC and HQ, adequate lag order is specified as 11 . In this way, it is seen that model verification tests are operating.

After specifying adequate lag order, in order to test the validity of VAR model, the first particular to look at is whether stability conditions are provided or not. Since the roots of VAR model don't go beyond the circular graphic, it can be stated the stability condition is provided. In the second stage, it is tested whether there is autocorrelation problem in the model or not by using Lagrance Multiple (LM) Test. When Table 4 is investigated, it is seen that null hypothesis is accepted such that in all the outcome of autocorrelation testing till the 12 th level, there is no autocorrelation. 


\section{Al Macrothink}

Table 4. Result of Autocorrelation LM Test

\begin{tabular}{llllll}
\hline Lag & LM_Stat. & Prob. & Lag & LM-Stat & Prob. \\
\hline 1 & 14.6815 & 0.1001 & 7 & 16.2044 & 0.0627 \\
2 & 5.0028 & 0.8341 & 8 & 7.7882 & 0.5556 \\
3 & 16.4836 & 0.0574 & 9 & 6.7996 & 0.6580 \\
4 & 9.0784 & 0.4301 & 10 & 4.6546 & 0.8633 \\
5 & 8.7181 & 0.3953 & 11 & 4.0541 & 0.9078 \\
6 & 16.2044 & 0.4637 & 12 & 14.6155 & 0.1021 \\
\hline
\end{tabular}

In the third stage, it is required for variable variance condition to be provided. Variable variance is tested by using White Heteroscedasticity test.

Table 5. Results of White Variable Variance Test

\begin{tabular}{lll}
\hline Chi-sq & df & Prob. \\
\hline 418.1024 & 396 & 0.2134 \\
\hline
\end{tabular}

When Table 5 is investigated, null hypothesis is accepted such that there is no variable variance in White variable variance test results.

Table 6. Pantula Principle (Trace Statistics)

\begin{tabular}{llll}
\hline Rank $(\mathbf{r})$ & Model 2 & Model 3 & Model 4 \\
\hline $\begin{array}{l}\text { None } \\
\mathrm{r}=0\end{array}$ & 0.0014 & 0.0002 & 0.0052 \\
$\begin{array}{l}\text { At Most } 1 \\
\mathrm{r} \leq 1\end{array}$ & 0.0114 & 0.0017 & $0.0502^{*}$ \\
$\begin{array}{l}\text { At Most 2 } \\
\mathrm{r} \leq 2\end{array}$ & 0.1034 & 0.0066 & 0.2129 \\
\hline
\end{tabular}

* Region where $\mathrm{H}_{0}$ hypothesis is accepted.

To establish the models in Table 6 is important to specify long term coefficient. The Pantula principle provides the opportunity to make choice among model 2, model 3 and model 4 which are seen most frequently among deterministic trends (Asterio and Hall, 2007: 327-328). According to the Pantula principle, the most suitable specification for our model is "Model 4". When Table 6 is investigated, it is seen that there is at most 1 cointegration between variables as per trend and intercept in model 4 . The below Table 7 shows the Johansen cointegration test results that are obtained by taking Model 4 as basis. 
Table 7. Result of Johansen Test for Cointegration

\begin{tabular}{|c|c|c|c|c|}
\hline $\begin{array}{ll}\text { Null Hypothesis } \\
\left(\mathrm{H}_{0}\right)\end{array}$ & $\begin{array}{l}\text { Alternative Hypothesis } \\
\left(\mathrm{H}_{1}\right)\end{array}$ & Eigenvalue & & $\begin{array}{l}\text { Critical Value } \\
(0.05)\end{array}$ \\
\hline$\lambda_{\text {trace }}$ test & & & $\lambda_{\text {trace value }}$ & \\
\hline $\mathrm{r}=0$ & $r>0$ & 0.2281 & 51.7485 & 42.9152 \\
\hline $\mathrm{r} \leq 1$ & $\mathrm{r}>1$ & 0.1592 & 25.8582 & 25.8721 \\
\hline$\lambda_{\text {mak }}$ test & & & $\lambda_{\text {mak }}$ value & \\
\hline $\mathrm{r}=0$ & $\mathrm{r}=1$ & 0.2281 & 25.8902 & 25.8232 \\
\hline $\mathrm{r}=1$ & $\mathrm{r}=2$ & 0.1592 & 17.3499 & 19.3870 \\
\hline
\end{tabular}

When Table 7 is investigated, as $\lambda$ trace and $\lambda$ mak values are bigger than critical values at significant level of $5 \%$, null hypothesis revealing that there is no cointegration relation between the variables is rejected, while the alternative hypothesis specifying that there is at least one cointegration relation between the variables is accepted. For this reason, in the model being predicted, the existence of cointegration relation has been determined.

Since meaningful results could not be obtained when a Weak exogeneity test is conducted, " $\mathrm{H}_{0}$ : variable is the weak exogenous" hypothesis is accepted. For this reason, short term behaviors of variables cannot be modeled. Error Correction Model-ECM model cannot be predicted.

In order to specify estimators of cointegration, FMOLS (Full Modified OLS) methods which are developed by Phillips and Hansen (1990) are used. FMOLS method ensure partial alternative to the ECM methodology. FMOLS is preferable in terms of asymptotic behavior (Phillips and Hansen, 1990:120). FMOLS provides of optimal estimated of co-integrating regressions. This method is obtained with the development of OLS where endogeneity and autocorrelation problem is considered (Phillips, 1993:1).

Table 8. FMOLS Results

\begin{tabular}{llll}
\hline Variable & Coefficient & t-Statistic & Prob. \\
\hline PPI & $0.385210^{* * *}$ & 1.884147 & 0.0623 \\
UNMP & $-1.751388^{* *}$ & -2.746907 & 0.0071 \\
C & $18.37054^{* *}$ & 2.546258 & 0.0123 \\
\hline
\end{tabular}

Note: Mac Knon ***,*** shows the critical values of $\% 1, \% 5$ and $\% 10$ respectively.

According to Table 8, a 1 percent increase in PPI, causes for IPI to increase by 0,4 percent. An increase of 1 percent in UNMP, causes for IPI to be reduced by 1.7 percent. If there are no changes in PPI and UNMP, in the long term IPI will approximately increase by 18.3 percent.

\section{Conclusion}

The research has been conducted by assuming that it would be helpful for market players, policy makers, and researchers to know about the impacts of PPI, unemployment and IPI in 
establishing economic stability in Turkey. In this study, the impact of PPI and unemployment on IPI has been investigated for the period of 2008:01-2017:03 in Turkey by using Johansen Cointegration analysis. In the study it is seen that the series which are used in unit root analysis are stationary at first difference. The existence of a long term relationship between the series is determined by Johansen Cointegration analysis. The result of the FMOLS test revealed that the coefficient of unemployment is negative with high influence and statistically significant while inflation is positive but has no significant effect on economic growth. Meaning that in the long term a 1 percent increase in unemployment will reduce IPI with a percent of 1.7 .

If economic growth cannot increase employment, it can be stated that there is disruption in income distribution. Turkey will be faced with this problem for many years. Besides, Turkey adopts a policy that is based on demand oriented growth models meaning that a policy based on growth depending on inflation is being adopted (İdikut Özpençe, 2016). Shortly, Turkey which needs inflation with demand push to achieve economic growth also needs structural reforms to reduce unemployment. High labor costs and low level of increase in efficiency are other obstacles in front of the objective to increase employment.

Economic stability and economic growth as being among macroeconomic targets are among the primary objectives to be realized in each economy. In order to meet these targets, first of all, it is required to use public and monetary policies. At the point where fiscal policies are implemented, political process is being influential. Within this content, it is required for policy makers to create policies to reduce unemployment in Turkey (and to reduce inflation on the other hand). In this way, it could serve for economic stability to be attained and for economic growth to be achieved.

In this context we believe that if the market is pursuing profit maximization it must pursue both growth and economic stability maximization in the state. Government should create information and technology externalities with regulatory and supervisory policies. These are among the quantitative features. Apart from these, government will have tasks at quantitative and qualitative dimensions.

Economic stability and growth complement each other. Low level of inflation and unemployment are considered as the engine of growth. However, there can be a limit for providing such a harmonization in economies. That is their being evaluated alone may cause technical mistakes. Because they are in interaction with each other. For example, a high economic growth and a low inflation target can cause us to confront an inflation and/or unemployment with a tendency to increase.

\section{References}

Akçay, S. (2011). The Causal Relationship between Producer Price Index and Consumer Price Index: Empirical Evidence from Selected European Countries. International Journal of Economics and Finance, 3(6), 227-232. http://dx.doi.org/10.5539/ijef.v3n6p227 
Alkin, E. (1969). Income Distribution Theory of Keynes and Kaldor Model. Journal of Faculty of Economics, 29(1-4), 131-159.

Arby, M.F., \& Ghauri, S.P. (2016). The Relationship between Wholesale Price Index and Consumer Price Index. SBP StaffNotes, 3(16), 1-8.

Asari, F.F.A.H. at al. (2011). Multivariate Time Series Analysis on Correlation between Inflation Rate and Employment Rate with Gross Domestic Product. World Applied Sciences Journal, Special Issue on Bolstering Economic Sustainability, 12, 61-66.

Asterio, D., \& Hall, S. (2007). Applied econometrics: a modern approach. (Revised Edition), China: Palgrave Macmillan. ISBN-13: 978-0230506404

Ball, L., \& Mankiw, N.G. (2002). The NAIRU in Theory and Practice. Journal of Economic Perspectives, 16(4), 115-136. http://dx.doi.org/10.1257/089533002320951000

Barro, R. J. (1990). Government Spending in a Simple Model Endogeneous Growth. The Journal of Political Economy, 98(5), 407-443. http://dx.doi.org/10.1086/261726

Birtek, F. (1985). The Rise and Fall of Etatism in Turkey, 1932-1950: The Uncertain Road in the Restructuring of a Semiperipheral Economy, Review (Fernand Braudel Center), 8(3), 407-438.

Clark, T.E. (1995). Do Producer Prices Lead Consumer Prices? Economic Review, Federal Reserve Bank of Kansas City. 25-39. [Online] Available: https://www.kansascityfed.org/publicat/econrev/pdf/3q95clar.pdf

Demiray, D. B. (1998). Monetary Approach to Foreign Currencies and Alternative Application for Turkey (Johansen Cointegration Analysis with Many Equations). D.E.Ü.İI.B.F. Journal, 13(2), 65-86.

Dickey, D.A, \& Fuller, W.A. (1979). Distribution of the Estimators for Autoregressive Time Series with a Unit Root. Journal of the American Statistical Association, 74(366), 427-431. http://dx.doi.org/10.1080/01621459.1979.10482531

Dickey, D.A., \& Fuller, W.A. (1981). Likelihood Ratio Statistics for Autoregressive Time Series with A Unit Root. Econometrica, 49(4), 1057-1072. http://dx.doi.org/10.2307/1912517

Domar, E. D. (1946). Capital Expansion, Rate of Growth, and Employment. Econometrica, 14(2), 137-147. https://doi.org/10.2307/1905364

Dwyer, G.P. (2015). The Johansen Tests for Cointegration. [Online] Available: http://www.jerrydwyer.com/pdf/Clemson/Cointegration.pdf (June 6, 2017)

Eker, A., Altay, A., \& Sakal, M. (1997). Fiscal policy (theory, principles and methods), (2nd ed.), İzmir: Anadolu Matbaacılık, (Cheapter 3).

Forstater, M. (2002). Unemployment in Capitalist Economies: A History of Thought for Thinking About Policy, Center for Full Employment and Price Stability, Working Paper 
No: 16. 1-21.

Friedman, M. (1968). The Role of Monetary Policy. The American Economic Review, 58(1), $1-17$.

Friedman, M. (1976). Inflation and Unemployment. 267-286. [Online] Available: http://www.nobelprize.org/nobel_prizes/economic-sciences/laureates/1976/friedman-lect ure.pdf (May 14, 2017)

Fulop, G., \& Gyomai, G. (2012). Transition of the OECD CLI System to a GDP Based Business Cycle Target. OECD Composite Leading Indicators Background Note, March. [Online] Available: http://www.oecd.org/std/leading-indicators/49985449.pdf (June 25, 2017)

Gujarati, D.N. (2004). Basic econometrics (4th ed.), New York: The McGraw-Hill Companies, (Chapter 4).

Haberler, G. (1967). Monetary and Fiscal Policy for Economic Stability and Growth. II Politicco, 32(1), 32-48.

Harrod, R.F. (1939). An Essay in Dynamic Theory. The Economic Journal, 49(193), 14-33. http://dx.doi.org/10.2307/2225181

İdikut Özpençe, A. (2016). Analysis of the Relationship Between Inflation and Economic Growth in Turkey. Journal of Economics, Finance and Accounting, 3(3), 180-191. http://dx.doi.org/10.17261/Pressacademia.2016321986

Jaradat, M.A. (2013). Impact of Inflation and Unemployment on Jordanian GDP. Interdisciplinary Journal of Contemporary Research in Business, 4(10), 317-334.

Jelilov, G., Obasa, O.J., \& Isik, A. (2016). Impact of Inflation and Unemployment on Economic Growth in Ten (10) Selected Member's States of Economic Community of West Africa States (ECOWAS) (2001-2014). Advances in Economics and Business, 4(5), 222-244. http://doi.org/10.13189/aeb.2016.040503

Johansen, S. (1988). Statistical Analysis of Cointegration Vectors. Journal of Economic Dynamics and Control, 12, 231-254. https://doi.org/10.1016/0165-1889(88)90041-3

Kaldor, N. (1957). A Model of Economic Growth. The Economic Journal, 67(268), 591-624. https://doi.org/10.2307/2227704

Köse, Z. (2016). Relationship of Economic Growth, Unemployment and Inflation in Turkish Economy for the Period of 2003-2014. Turkish Social Sciences Research Journal, 1(1), 56-74.

Lucas, R.E. (1972). Expectations and the Neutrality of Money. Journal of Economic Theory, 4(2), 103-124. https://doi.org/10.1016/0022-0531(72)90142-1

Lucas, R.E. (1988). On The Mechanics of Economic Development. Journal of Monetary Economics, 22(1), 3-42. https://doi.org/10.1016/0304-3932(88)90168-7 
Mankiw, N.G. (1990). A Quick Refresher Course in Macroeconomics. Journal of Economic Literature, 28(4), 1645-1660.

Mohseni, M., \& Jouzaryan, F. (2016). Examining the Effects of Inflation and Unemployment on Economic Growth in Iran (1996-2012). Procedia Economics and Finance, 36, 381-389. https://doi.org/10.1016/S2212-5671(16)30050-8

Musgrave, R.A., \& Musgrave, P.B. (1989). Public finance in theory and practice (5th ed.), New York: McGraw-Hill International Editions, (Chapter 1).

Muth, J.F. (1961). Rational Expectations and the Theory of Price Movements, Econometrica, 29(3), 315-335. https://doi.org/10.2307/1909635

Okun, A.M. (1962). Potential GNP: Its Measurement and Significance. Cowles Foundation Paper 190, Reprints, Yale University. https://milescorak.files.wordpress.com/2016/01/okun-potential-gnp-its-measurement-an d-significance-p0190.pdf (June 6, 2017)

Pasini F.L. (2013). Economic Stability and Economic Governance in The Euro Area: What The European Crisis Can Teach on The Limits of Economic Integration. Journal of International Economic Law, 16(1), 211-256. https://doi.org/10.1093/jiel/jgt003

Phelps, E.S. (1968). Money-Wage Dynamics and Labor-Market Equilibrium. Journal of Political Economy, 76(4), Part 2: Issues in Monetary Research. 678-711. https://doi.org/10.1086/259438

Phillips, A.W. (1958). The Relation between Unemployment and the Rate of Change of Money Wages in the United Kingdom, 1861-1957. Economica, 25(100), 283-299. https://doi.org/10.2307/2550759

Phillips, P.C.B. (1993). Fully Modified Least Squares and Vector Autoregression. Cowles Foundation Discussion Paper No. 1047. http://dx.doi.org/10.2307/2171721

Phillips, P.C.B., \& Hansen, B.E. (1990). Statistical Inference in Instrumental Variables Regression with I(1) Process. Review of Economic Studies, 57, 99-125. https://doi.org/10.2307/2297545

Phillips, P.C.B., \& Perron, P. (1988). Testing for a Unit Root in Time Series Regression. Biometrika, 75(2), 335-346. https://doi.org/10.2307/2336182

Resurreccion, P.F. (2014). Linking Unemployment to Inflation and Economic Growth: Toward A Better Understanding of Unemployment in The Phillippines. Asian Journal of Economic Modelling, 2(4), 156-168.

Romer, P.M. (1986). Increasing Returns and Long-Run Growth. The Journal of Political Economy, 94(5), 1002-1037.

Sa'idu B. M., \& Muhammad A. A. (2015). Do Unemployment and Inflation Substantially Affect Economic Growth?, Journal of Economics and Development Studies, 3(2), 132-139. http://dx.doi.org/10.15640/jeds.v3n2a13 
Şahbudak, E., \& Şahin, D. (2016). Türkiye'de İşsizliğin Belirleyicileri Üzerine Ampirik Analiz. Kesit Akademi Dergisi, 2(3), 85-96. http://dx.doi.org/10.18020/kesit.31

Samuelson, P.A., \& Solow, R.M. (1960). Analytical Aspects of Anti-Inflation Policy. The American Economic Review, 50(2), 177-194.

Samuelson, P.A., \& Solow, R.M. (1960). Analytical Aspects of Anti-Inflation Policy. The American Economic Review, 50(2), 177-194.

Şentürk, M., \& Akbaş, Y.E. (2014). İşsizlik-Enflasyon ve Ekonomik Büyüme Arasındaki Karş1lıklı İlişkinin Değerlendirilmesi: Türkiye Örneği. Journal of Yasar University, 9(34), 5820-5832. http://dx.doi.org/10.19168/jyu.43548

Shadid, M. (2014). Effect of Inflation and Unemployment on Economic Growth in Pakistan. Journal of Economics and Sustainable Development, 5(14), 103-107.

Solow, R.B. (1956). A Contribution to the Theory of Economic Growth. The Quarterly Journal of Economics, 70(1), 65-94. https://doi.org/10.2307/1884513

Stein, H. (1956). Policies for Economic Growth and Stability. Journal of Farm Economics, 38(5), 1159-1172.

Thayaparan, A. (2014). Impact of Inflation and Economic Growth on Unemployment in Sri Lanka: A Study of Time Series Analysis. Global Journal of Management and Business Research: B Economics and Commerce, 13(5), 44-54.

Ulusoy, A. (2016). Fiscal policy, Umuttepe Publication No: 161, Business Administration-Economics series: 64, Umuttepe Publication: Trabzon, (Chapter 2).

Umair, M., \& Ullah, R. (2013). Impact of GDP and Inflation on Unemployment Rate: A Study of Pakistan Economy in 2000-2010. International Review of Management and Business Research, 2(2), 388-400.

Vermeulen, C. (2015). Inflation, Growth and Employment in South Africa: Trends and Trade-Offs. ERSA Working Paper 547, Sept. 1-28. [Online] Available: https://econrsa.org/system/files/publications/working_papers/working_paper_547.pdf

Wajid, A., \& Kalim, R. (2013). The Impact of Inflation and Economic Growth on Unemployment: Time Series Evidence from Pakistan. 3rd. International Conference on Business Management, Lahore Pakistan, February 27-28 2013, http://cgr.umt.edu.pk/icobm2013/papers/Papers/IC3-Dec-2012-083.pdf, (November $12, .2016)$.

Yelwa, M., David, O.O.K., \& Omoniyi, E. (2015). Analysis of the Relationship between Inflation, Unemployment and Economic Growth in Nigeria: 1987-2012. Applied Economics and Finance, 2(3), 102-109. https://doi.org/10.11114/aef.v2i3.943

Yüksel S. (2016). Causality relation between economic growth, unemployment and inflation in Russian Economy. Finance Political and Economic Interpretations, 53(614), 43-58. 


\section{Macrothink}

\section{Copyright Disclaimer}

Copyright for this article is retained by the author(s), with first publication rights granted to the journal.

This is an open-access article distributed under the terms and conditions of the Creative Commons Attribution license (http://creativecommons.org/licenses/by/3.0/). 